\title{
Application of Computer Aided Process Design in CNC Machining of Spiral Bevel Gears
}

\author{
Zhu Xiurong, Liu Yang, Ding Dapeng and Sun Zhijie \\ College of Mechanical Engineering, Jilin Teacher's Institute of Engineering and \\ Technology, Changchun, Jilin, China 130052 \\ zxr67811@163.com
}

\begin{abstract}
Use of computer aided process planning in CNC machining of spiral bevel gear, not only can improve overall parts manufacturing level, but also can greatly improve the quality of the products, by the driving bevel gear, planning process of driven bevel gear and the assembly process, understanding calculation computer aided process design can improve the work efficiency, accelerate the market response speed, shorten technical preparation cycle. At the same time, promote the standardization of the construction process, improve the process design. Optimizing design process, promote technological progress. Will bring greater social and economic benefits.
\end{abstract}

Keywords: Computer aided process design; spiral bevel gear; CNC machine tool; machining process; simulation

\section{Introduction}

With the continuous development of industry, output of spiral bevel gear production also in rapid growth. In gear transmission, especially in the axis of intersection of mechanical transmission, straight bevel gear is applied widely. Because of the straight bevel gear spiral bevel gear is easy to design and processing, the tooth line in mechanical transmission also does not produce axial force. However, in the process of mechanical transmission, in terms of motion stability and bearing capacity. Straight bevel gear is not spiral bevel gear. Spiral bevel gear has high strength, able to work more steadily, suitable for relatively large gear deceleration, tooth wear uniform, improve the contact area, can improve the tooth face roughness and a significant reduction in noise. So in the car almost universal use of spiral bevel gear. To this end, we propose spiral bevel gear design and processing theory parameters and simulation research is very necessary. Computer aided process design, in the spiral bevel gear NC machining plays very important role, to improve the product quality.

\section{Design Requirements of the Active Bevel Gear and its Processing Technology}

\subsection{The Design Requirements of the Spiral Bevel Gear Drive Gear Are Shown in Figure 1.}

The spatial staggered axis drives the spiral motion of the relative motion, and the spiral axis rotates around the axis of the gear to form a double curved surface.

To burr and sharp edge. 
Heat treatment: carburizing and quenching.

Surface hardness: 59HRC above, the effective depth of hardening layer: tooth root, DC $550 \mathrm{H} 1 \mathrm{~V}$ 1.0-2.0; DC $550 \mathrm{H} 1 \mathrm{~V}$ 1.6-2.2; core hardness 30-40HRC; metallographic test, the residual austenite is not greater than A0.8, M-6.5. by shot before grinding tooth: shot treatment pill for cast steel shot or shot. The average particle size is $\varnothing 0.8$, the hardness by 550-650HV according to YB/T5149., the rest of the shot intensity above 0.6, coverage of more than $300 \%$, parts of the surface after shot at $0.05-0.10$, hardness is $750 \mathrm{HV}$, then, according to the backlash, contact and noise matching gear, after lapping. After matching, on the surface with a pencil cut out the assembly sequence matching gear, according to the contact in the test machine, adjust the backlash and noise, the difference from the actual assembly and theory. From the actual assembly is larger than the distance theory assembly is positive, otherwise negative. At the same time in the table Face to make the company mark, series.

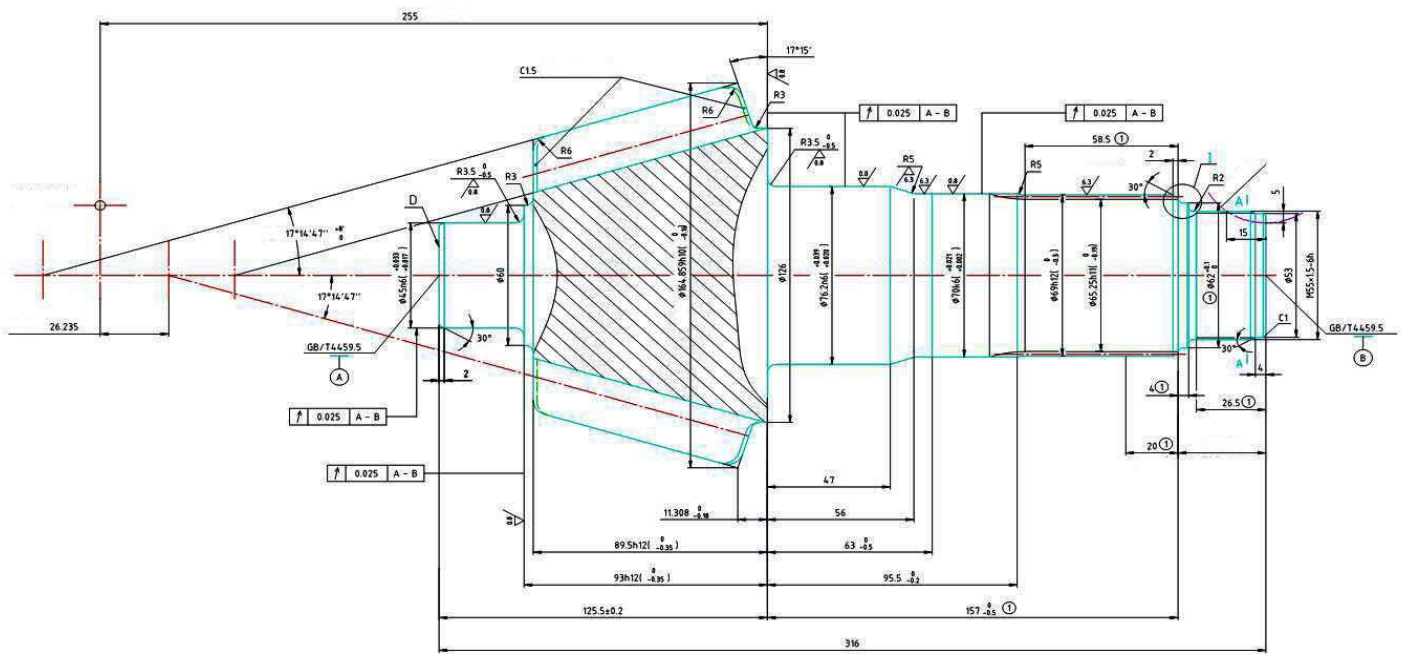

Figure 1. Active Bevel Gear Parts

\subsection{Active Bevel Gear Design Parameters}

With the development of computer technology, electronic form software, database in accelerating development, for spiral bevel and hypoid gear, quasi hypoid gear tedious data computing and intelligent use, providing great convenience. The use of modern computer spreadsheet software can be quasi hyperboloid gear form customization, rapid processing of complex data, very convenient, high-efficient data analysis and calculation.

Table 1. Design Parameters of Active Bevel Gears

\begin{tabular}{|l|l|}
\hline Offset of hyperbolic gear & 30 \\
\hline Tooth number & 9 \\
\hline Midpoint normal modulus & 9.649 \\
\hline Tooth top height & 14.252 \\
\hline whole depth & 21.71 \\
\hline
\end{tabular}




\begin{tabular}{|l|l|}
\hline Average pressure angle & $22^{\circ} 30^{\prime}$ \\
\hline Spiral angle & $40^{\circ} 36^{\prime}$ \\
\hline Spiral direction & Left \\
\hline Diameter of cutter head & 320 \\
\hline Tooth side gap & $0.3-0.4$ \\
\hline $\begin{array}{l}\text { The tooth gap variable of the same pair of gears is not } \\
\text { larger than the one. }\end{array}$ & 0.08 \\
\hline Tooth surface accuracy & $8(\mathrm{~GB} / \mathrm{T} 11365)$ \\
\hline Tooth surface roughness & $\mathrm{Z}=37$ \\
\hline Tooth number of paired gears & \\
\hline
\end{tabular}

\subsection{Machining Process of Drive Bevel Gear}

Table 2. Machining Process of Drive Bevel Gear

\begin{tabular}{|c|c|c|c|c|c|c|c|c|c|c|c|c|c|}
\hline \multirow{3}{*}{\multicolumn{2}{|c|}{ Gear workshop }} & & & & \multicolumn{4}{|c|}{ Part drawing change mark } & & \multirow{3}{*}{\multicolumn{2}{|c|}{$\begin{array}{l}2402036 \mathrm{DA} 6 \mathrm{~A} \\
\text { Drive bevel gear }\end{array}$}} & \multirow[b]{4}{*}{ Each car number } & \multirow{4}{*}{ er 1} \\
\hline & & \multirow{2}{*}{\multicolumn{3}{|c|}{ Process engineering }} & \multirow{2}{*}{$\begin{array}{l}\text { Advice note } \\
\text { Sign }\end{array}$} & \multicolumn{2}{|c|}{ sz2006-009 } & & \multirow{3}{*}{ Part name } & & & & \\
\hline & & & & & & \multirow{2}{*}{ is $165-185 \mathrm{HB}$} & \multirow{2}{*}{\multicolumn{2}{|c|}{ Net weigh $13.6 \mathrm{KG}$}} & & & & & \\
\hline Route & Calcine-Gear-Heat up-Gear-Heat up Assembly unit & Gear & Part materia F & FAS3226H Types of embryo Calcine Rough hardne? & Rough hardness & & & & & \multicolumn{2}{|c|}{ Motorcycle SR 130498 } & & \\
\hline No. & Process name & Plan No: & Equipment & Equipment Name & Clamping & $s$ & $\mathrm{n}$ & 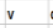 & coolant liquid & Ttest & & Remarks & \\
\hline \multirow[t]{2}{*}{1} & end milling, hit center & 06-001 & E2U696 & end milling,hit center machine & D33-20213 & Milling150 & 350 & 154 & & 2 & & & \\
\hline & & & & & & Bit75 & 860 & 17 & & & & & \\
\hline 2 & Rough. Fine vehicle end face outer circle & 06-006 & CK7820B & CNC lathe & D31-14288 & 0.3 & & 150 & Emulsified liquid & 7 & & & \\
\hline 3 & Rough، Fine vehicle conical surface, excircle & 06-010 & CK7820B & CNC lathe & D31-14287 & 0.3 & & 150 & Emulsified liquid & 7 & & & \\
\hline 4 & Milling flutes & 06-011 & X6132A & Horizontal milling machine & D3314105 & 100 & 150 & 38 & & 1.5 & & & \\
\hline \multirow[t]{2}{*}{5} & Milling spline & $06-013$ & YB6212 & Universal spline machine & D33-20165 & 1.6 & 200 & 47 & 32स Total system loss & 13 & & & \\
\hline & & 06-014 & YB6212 & Universal spline machine & D33-20165 & 1.6 & 200 & 47 & 32A Total system loss & 13 & & & \\
\hline 6 & Mowaiyuan & $06-018$ & MK1632 & CNC angular approach cylindrical grinding machine & $D C .50$ & 0.005 & 120 & 50 & & 4.5 & & & \\
\hline 7 & Liquid extrusion screw thread & $06-021$ & Za228-20 & Liquid fllament machine & D32-20070 & 0.1 & 16 & 8 & 32A Total system loss & 1.2 & & & \\
\hline $8 \mathrm{~J}$ & Intermediate survey & & & & & & & & & & & & \\
\hline 9 & Gear milling & $06-030$ & c60 & CNC bevel gear milling machine & D33-20156 & $0.03-0.15$ & & & 32स Total system loss & 20 & & & \\
\hline 10 & Longitudinal correction & $06-043$ & & Bevel gear chamfering machine & D33-14191 & 12seclgear & & $55-85$ & & 1.2 & & & \\
\hline 11 & Clean & $06-153$ & 202106 & Cleaning machine & & & 50 & 13 & & 1.3 & & & \\
\hline $12 \mathrm{~J}$ & Intermediate survey & D6-111 & 600HTT & CNC bevel gear testing machine & D33-20157 & & & & & & & & \\
\hline 13 & Heat treatment & & Y9250 & & & & & & & & & & \\
\hline 14 & Longitudinal correction & $06-044$ & YMDV -50 & Bevel gear chamfering machine & D33-20282 & 3seclgear & 50 & 50 & & 2.5 & & & \\
\hline 15 & Fine grinding outer circle, end face & $06-048$ & MK1632 & CNC angular approach cylindrical grinding machine & DC.50 & 0.003 & 120 & 50 & Soda water & 1.8 & & & \\
\hline 16 & Fine grinding outer circle 、 end face & $06-051$ & MK1632 & CNC angular approach cylindrical grinding machine & $\mathrm{DC}-50$ & 0.003 & 120 & 50 & Soda water & 1.8 & & & \\
\hline 17 & Correct thread & & & & $36-14488$ & & & & & 3 & & & \\
\hline 18J & Final inspection & & & & & & & & & & & & \\
\hline
\end{tabular}




\section{Design Requirements of the Driven Bevel Gears and its Processing Technology}

\subsection{The Design Requirements of the Driven Bevel Gears are shown in Figure}

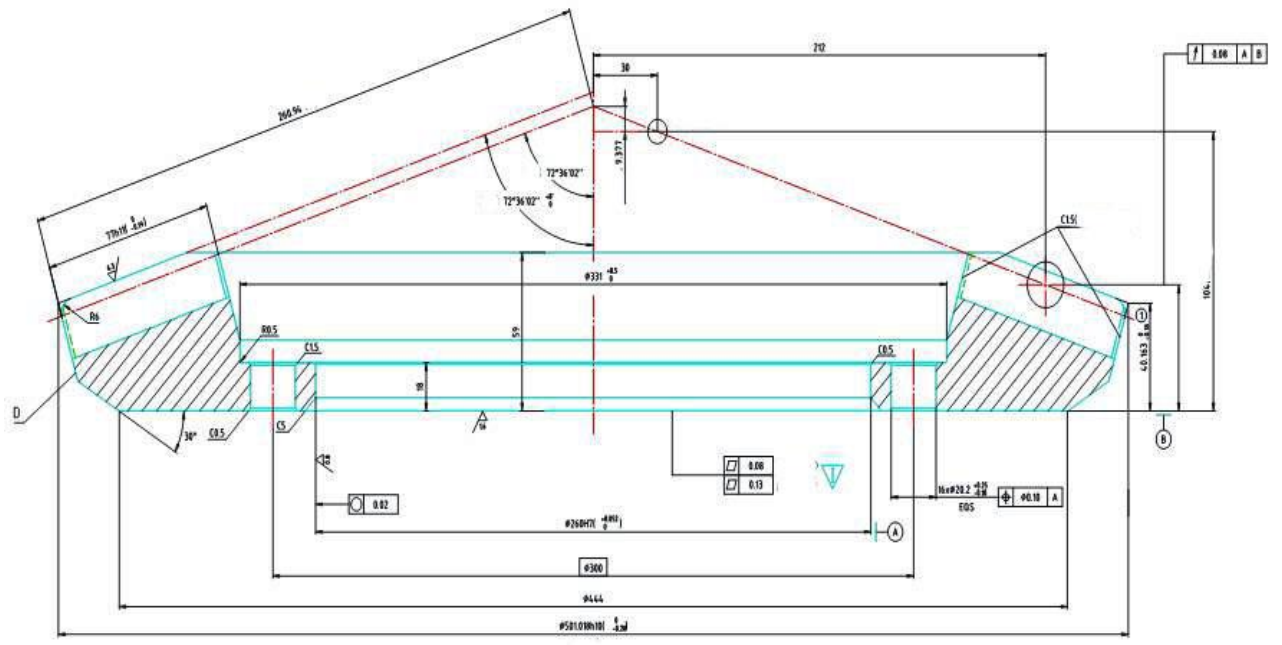

Figure 2. Driven Bevel Gear Parts

Heat treatment: carburizing and quenching, surface hardness: 59HRC above, the effective depth of hardening layer, tooth root: DC 550 H1V 1.0-2.0; the pitch circle, DC 550 H1V 1.6$2.2 ; 30-40 \mathrm{HRC}$ core hardness; metallographic test, the residual austenite is not greater than A0.8, M-6.5. by Shot: grinding teeth root shot treatment pill for cast steel shot or shot, average particle size is $\varnothing 0.8$, the hardness by $550-650 \mathrm{HV}$ according to YB/T5149. the rest of the shot intensity above 0.6 , coverage of more than $300 \%$, parts of the surface after shot at 0.05-0.10, hardness is $750 \mathrm{HV}$, then, according to the tooth gap, the contact pattern and noise matching gear, after lapping after pairing. On the surface, with a pencil cut out assembly serial mating gear, according to the contact in the test machine, adjust the backlash and noise, the difference from the actual assembly and theory. From the actual assembly is larger than the distance theory assembly is positive, reverse As a negative value, and at the same time to make the company's mark on the surface, the series.

\subsection{The Design Parameters of Driven Bevel Gears}

The use of computer software, driven bevel gear form customization, rapid processing of complex and cumbersome data, very convenient and fast data analysis and calculation.

Table 3. Design Parameters of Driven Bevel Gears

\begin{tabular}{|l|l|}
\hline Offset of hyperbolic gear & 30 \\
\hline Tooth number & 37 \\
\hline Midpoint normal modulus & 9.649 \\
\hline Pitch circle diameter & 498 \\
\hline Tooth top height & 5.046 \\
\hline
\end{tabular}




\begin{tabular}{|l|l|}
\hline Tooth full height & 21.71 \\
\hline Average pressure angle & $22^{\circ} 30^{\prime}$ \\
\hline Spiral angle & $32^{\circ} 45^{\prime} 22^{\prime \prime}$ \\
\hline Spiral angle & Right \\
\hline Diameter of cutter head & 320 \\
\hline Tooth side gap & $0.3-0.4$ \\
\hline $\begin{array}{l}\text { The tooth gap variable of the same pair of } \\
\text { gears is not larger than the one }\end{array}$ & 0.08 \\
\hline Gear precision grade & $8(\mathrm{~GB} / \mathrm{T} 11365)$ \\
\hline Tooth surface roughness & $\mathrm{Z}=9$ \\
\hline Tooth number of paired gears & \\
\hline
\end{tabular}

\subsection{Machining Process Of Driven Bevel Gear}

\section{Table 4. Machining Process of Driven Bevel Gear}

\begin{tabular}{|c|c|c|c|c|c|c|c|c|c|c|c|c|}
\hline \multirow{3}{*}{\multicolumn{2}{|c|}{ Gear workshop }} & \multirow{3}{*}{\multicolumn{3}{|c|}{ Process engineering }} & \multicolumn{4}{|c|}{ Part drawing change mark } & \multirow{3}{*}{$\begin{array}{l}\text { Part number } \\
\text { Part name }\end{array}$} & \multirow{3}{*}{\multicolumn{2}{|c|}{$\begin{array}{l}2402036 \mathrm{DA} 6 \mathrm{~A} \\
\text { Driven bevel gear }\end{array}$}} & \multirow{4}{*}{\begin{tabular}{|l|l|} 
\\
\end{tabular}} \\
\hline & & & & & \multirow{3}{*}{$\begin{array}{l}\text { Advice note } \\
\text { Sign }\end{array}$} & \multicolumn{2}{|c|}{ SZ2006-009 } & & & & & \\
\hline & & & & & & & & & & & & \\
\hline \multirow[b]{2}{*}{ Route } & \multirow[b]{2}{*}{ Calcine-Gear-Heat up-Gear-Heat up Assembly unit } & \multirow[b]{2}{*}{ Gear } & \multirow[b]{2}{*}{ Part material } & & & \multicolumn{3}{|c|}{ Net weight } & & & & \\
\hline & & & & FAS3225H Types of embryd Calcine Rough hardn & itough hardnes: & 165-185HB & & $38.89 \mathrm{kG}$ & & \multicolumn{3}{|c|}{ Motorcycli SR130498 Each car number 1} \\
\hline No. & Process name & Plan No: & oEquipment & Equipment Nlame & Clamping & s & n & $v$ & Coolant liquid & I test & Burthenth $\mathrm{h}$ & Remarks \\
\hline \multirow[t]{2}{*}{1} & Face cutting 、 Bore 、 Chamfering & 06.054 & CK516A & Vertical CIC lathe & 516AA1001T & 0.35 & & & Emulsified liquid & 7.5 & & \\
\hline & & 06.359 & LZ.КНЮВВ.КНВ & B Cantilever crane & & & & & & & & \\
\hline \multirow[t]{2}{*}{2} & Surface cone 、 Back cone 、 Eendocone & 06.059 & CK516A & Vertical CNC lathe & 516AA1004T & 0.35 & & & Emulsified liquid & 7.5 & & \\
\hline & & 06.361 & L2.КННВВККНВ & B Cantilever crane & & & & & & & & \\
\hline \multirow[t]{3}{*}{3} & Drill hole 、 Chamfering & 06.065 & ZK1640 & Digital controlled drill & D32.20185 & 0.16 & 400 & & Emulsified liquid & 10 & & \\
\hline & & 06.328 & DHK40 & Digital controlled drill & DH.805-20001 & 0.16 & 400 & & Emulsified liquid & 10 & & \\
\hline & & $06: 212$ & 23025 & Drilling machine with pivoted arm & D32.150024 & 0.16 & 400 & & Emulsified liquid & 10 & & \\
\hline $4 \mathrm{~J}$ & Intermediate survey & & & & & & & & & & & \\
\hline \multirow[t]{2}{*}{5} & Gear milling & 06.042 & $\mathrm{C6O}$ & CNC bevel gear milling machine & WH145910A & 0.05 & 75 & & 32 2 Total system lo & 1020 & & \\
\hline & & $06.376 \mathrm{c}$ & $0.25 T$ & Cantilever crane & & & & & & & & \\
\hline 6 & Longitudinal correction & $06-993 \gamma$ & Y9250 & Bevel gear chamfering machine & D33.-14395 & 2 seclgear 5 & & & & 2.5 & & \\
\hline 7 & Clean & $06-045$ & 202107 & Cleaning machine & & & & & & 2 & & \\
\hline $8 \mathrm{~J}$ & Intermediate survey & $06-111$ & 600HTT & CNC bevel gear testing machine & D33-20157 & & & & & & & \\
\hline 9 & Heat treatment & & & & & & & & & & & \\
\hline 10 & End relief & $06-193 \gamma$ & YMDV.50 & Bevel gear chamfering machine & J02-2037 & 2 2seclgear 5 & ar 50 & & & 3.5 & & \\
\hline \multirow[t]{2}{*}{11} & Grinding hole & $06-195$ & MR60.GH & Vertical numerical control inner hole end surface $\mathrm{g}$ & gD31-20123 & 0.0046 & 60 & & Emulsified liquid & 4.5 & & \\
\hline & & 06.290 & $0.25 T$ & Cantilever crane & & & & & & & & \\
\hline $12 \mathrm{~J}$ & Final inspection & & & & & & & & & & & \\
\hline
\end{tabular}

\section{Technical Specification for Matching Between 4 Bevel Gears and Driven Bevel Gears}

Computer aided process design provides a platform for information analysis of NC machining. Parts database contains all the parts processing process knowledge of the process, and lays the foundation for numerical control (CNC) machining. Because $\mathrm{CNC}$ system can determine the parts required for processing all kinds of information. Therefore, computer aided process planning is in $\mathrm{NC}$ machining of parts is one of the most important a part of the, can directly affect the quality of the product.

Also in the NC machining, machining process is an important link between the contact part and product processing, and the traditional process does not apply to the requirements of modern machining. To determine the above parts processing all kinds of information, select a processing method, right click on the processing method of button, can automatically generate processes, can also choose to process list. Computer aided process planning (CAPP) is the 
intermediate link of $\mathrm{CAD}$ and $\mathrm{CAM}$, can generate technology document is processing procedures.

\section{Table 5. Technical Regulation of Driven Bevel Gear and Driven Bevel Gear}

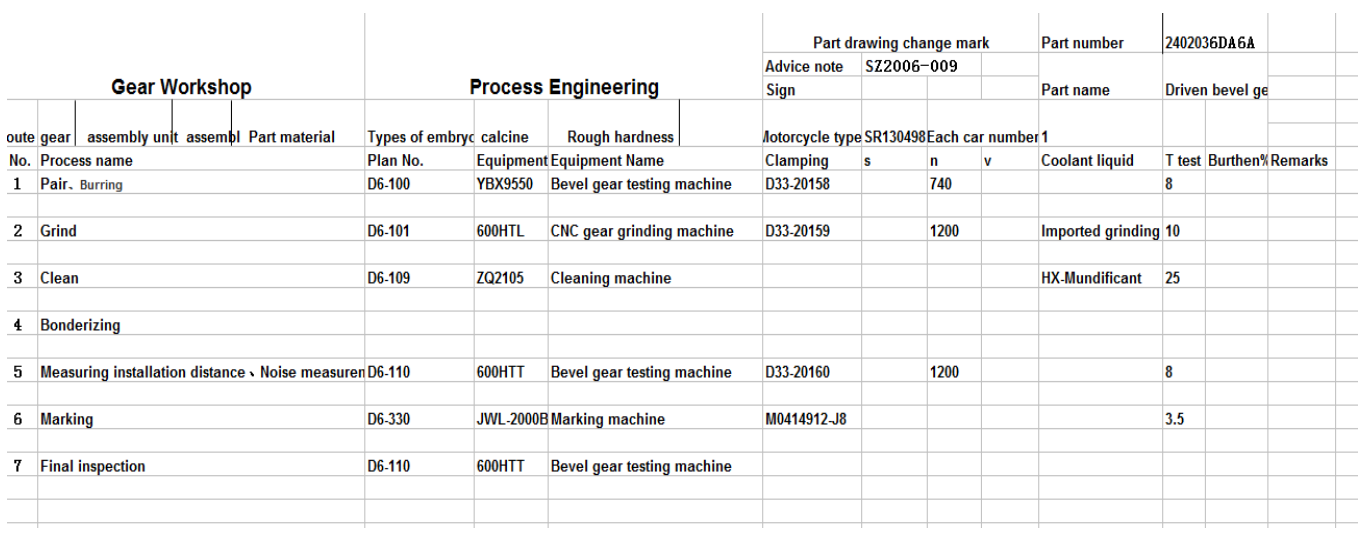

\section{Computer Aided Process Design in the Process of Application}

Computer aided process design of CAPP, with CAD, CAPP, CAM cell technology has become increasingly mature, and because the proposal and development of CIMS and IMS, prompting CAPP to the intelligent, integrated and practical direction. CAPP in modern manufacturing industry, has important theoretical significance and wide practical needs because. The application of CAPP system can not only improve the process design efficiency and quality, shorten the preparation period of technology, for the majority of technical staff from the tedious, repetitive labor provides a feasible way to process can put more in process testing and process research, but also can be standardized to ensure consistency of the process. Design, is conducive to promote standardization of technology. More important is the process of BOM data is to guide enterprises in the procurement of materials, production scheduling, production organization, resource balance, cost accounting and other important Basis, the application of CAPP system will lay a solid foundation for the integration of enterprise data information. Will CAPP Technology Application in the NC machining, can greatly improve the design and manufacture level of enterprise. On machined surface quality produced direct effect on. CAPP technology can guarantee the standardization of process design and standard. With the wide application of computer technology in modern enterprise, to computer as the carrier of aided process design has been by the theory gradually to practice. Application of computer aided process planning in NC machining: the application of NC machining of computer aided process planning, will greatly enhance the quality of process documents.

Application of CAPP system for process design, can:

1.To improve the efficiency of process design, speed up the market response speed and shorten the technical preparation period.

2.To improve the quality of process design, reduce the cost of product maintenance. 3.To help process engineers from the tedious, repetitive low levels of labor liberation, there is more energy into the process of testing, process research, optimize the process design, and promote technological progress.

4.To promote the standardization of the construction process, improve the design of the process of scientific, accurate and standardized. 
5.For the enterprise management information system in real time to provide the correct process data, for the enterprise information construction to improve the source information. 6.To promote the reform and development of computer related process technology.

\section{Spiral Bevel Gear Simulation}

Before NC machining, through repeated simulation processing in the software can not only detect process parameters setting, tool, work piece deformation and an overload situation. Moreover, but also the use of CNC machining simulation, geometric parameters on the processing and mechanical properties make analysis and evaluation, in order to improve the numerical control cutting conditions, improve the processing quality.

\subsection{Forming Process Driven Bevel Gear}

In CATIA software or UG software, based on the adjustment of the parameters, the establishment of the machine tool coordinate system, the driven bevel gear coordinate system, the cutter wheel coordinate system. According to the adjustment parameters, complete the modeling.

\subsection{Optimize the Surface Processing Technology, Determine the Reasonable Parameters}

Repeated parameter setting, the simulation of $\mathrm{CNC}$ machining, select the optimal parameters, determine the best plan. Spiral bevel gear simulation processing as shown in Figure 3:

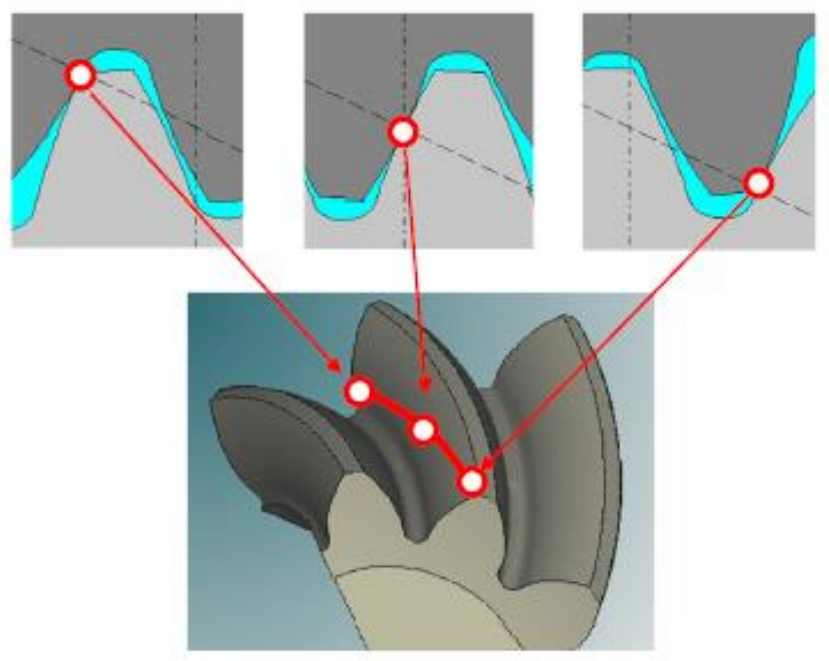

Figure 3. Design of Active Spiral Bevel Gears 


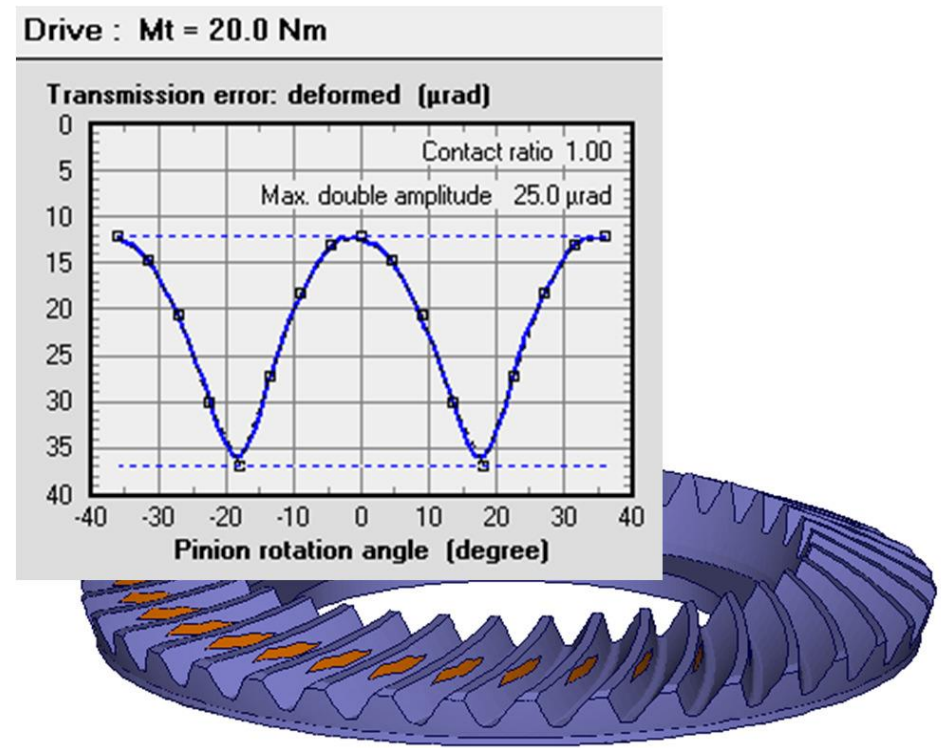

Figure 4. Design of Driven Spiral Bevel Gears

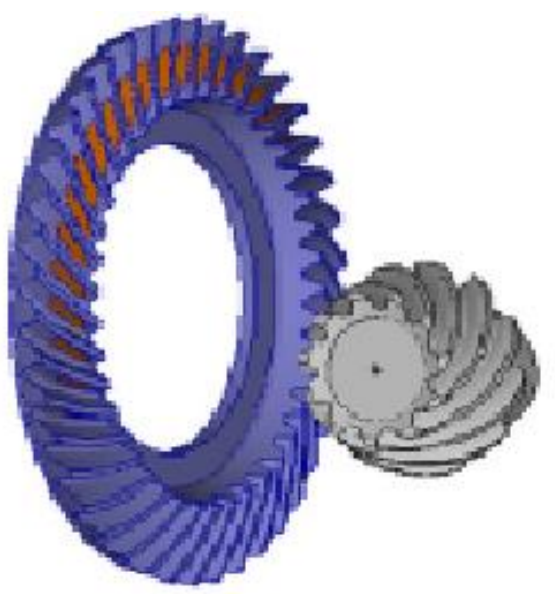

Figure 5. Simulation of Spiral Bevel Gears

\section{Concluding Remarks}

Through the active bevel gear, planning process of driven bevel gear and the assembly process, using computer aided process planning in NC machining of parts can not only improve overall parts manufacturing level, but also can greatly improve the quality of the products, so that the processing craft and the quality of the products guarantee.

In addition, the computer aided process design can improve the efficiency of process design, speed up the market response speed and shorten the technical preparation period. Promote the process standardization construction, improve the level of process design and optimize the process design, and promote technological progress. As long as the appropriate adjustment and modification according to different tool specifications and materials, can be 
applied in the field of numerical control processing, will bring greater social and economic benefits.

\section{References}

[1] X. Y. Lu, "J. Research on Machining Theory of Spiral Bevel Gear NC Machine Tool”,Scientific Publishers American, (2002).

[2] W. Zhang, T. Wang, H. He and H. Deng, "J. Network Improvement Scheme of Numerical Control Simulation System", Machine Tool and Hydraulic Pressure, vol. 10, (2006), pp. 165 166,199.

[3] K. Wang and J. Feng, "J . High Efficiency Machining Technology for Large Forgings", Journal of Harbin University of Science and Technology, vol. 2, (2013), pp. 65-67.

[4] Y. Cheng, L. Liu, J. Qian, Y. Gong and H. Shi, "J . Automotive Panel Die Machining Technology of Hardened Steel", Journal of Harbin University of Science and Technolog, vol. 2, (2013), pp. 13-15.

[5] F. L. Litvin and A. Fuentes, "Gear geometry and applied theory, Cambridge University Press", Cambridge, (2004).

[6] Z. Wei and W. Taiyong, "A Virtual System Solution of CNC Machine for Spiral Bbevel and Hypoid Gears", Transaction of Tianjin University, vol. 12, no. 5, (2006), pp. 373 377.

[7] W. Zhang, "J. The Theory and Simulation of NC Machining of The Quasi Hyperbolic Gear", TianJin University, (2007).

[8] J. He, "Application of computer aided process design in The Mold NC", J. Educational Technology and Equipment in China, (2012,06).

[9] J. Chen, "Application of Computer Aided Process Design Technology in Numerical Control Mold Processing", J.Coal Mining Machinery, $(\mathbf{2 0 1 3 , 1 0 )}$

[10] L. Song, "The Development of CAD/CAPP/CAM Integrated System Based on 2D Graphics", Hunan University, (2009,04). 
International Journal of Control and Automation Vol. 9, No. 9 (2016) 